\title{
Coal Characteristics and Cleat Attributes of Muara Enim Formation in Ulak Lebar and Surroundings Area, Lahat Regency, South Sumatra
}

\author{
M.A Rahmawati ${ }^{1, *}$, S.L Sari $^{1}$, A.Triyoga ${ }^{1}$, Idarwati ${ }^{1}$ \\ ${ }^{1}$ Sriwijaya University, Jl. Srijaya Negara, Bukit Besar, Ilir Barat I Kota Palembang 30139
}

\author{
* Corresponding author: armiliatya@gmail.com \\ Telephone/Fax. (0711) 370178/352870 \\ Received: 27 Des, 2017. Revised: 16 Apr, 2018, Accepted: 24 May, 2018, Published: 1 June 2018 \\ DOI 10.24273/jgeet.2018.3.2.586
}

\begin{abstract}
The research conducted in Ulak Lebar Area, Lahat Regency, South Sumatra. The focus of this study is on the Muara Enim Formation as it is known as the main coal-bearing formation in South Sumatra Basin. The research is aimed to determine the characteristics of coal based on its physical properties, also knowing the cleat development at the coal seam in the research area. The methods used such as literature study, field observation and laboratory test. Field observations included the observations of coal megascopic appearance and cleat attributes analysis such as the measurements of cleat orientation, aperture, spacing and length. The analysis result of cleat at LP 2A and LP 2B shows a relatively similar such as spacing value ranged between $6-9 \mathrm{~cm}$ and $5.5-8.6 \mathrm{~cm}$ while the aperture value ranged from $0.05-0.2 \mathrm{~cm}$, and $0.05-0.25 \mathrm{~cm}$, whereas at LP 67 the spacing value ranged from 1.5 to $3.3 \mathrm{~cm}$ and the aperture valued between $0.1-0.3 \mathrm{~cm}$. A rather significant difference between the cleat spacing values of LP 67 towards both previous observation stations is indicated by the geological processes occurred during the coalification process thus affected the development of cleats in coal, the geology structure control is characterized by a relatively large aperture and smaller spacing values. The laboratory test conducted is maceral analysis, shows the coal in the research area is dominantly composed of vitrinite $(74,8 \%$ and the vitrinite reflectance value is 0,40 indicating the coal classified as sub-bituminous rank.
\end{abstract}

Keywords: Coal, Cleat, Muara Enim Formation

\section{Introduction}

Coal is a combustible sedimentary rock, containing more than $50 \%$ to $70 \%$ of carbon content derived from plant material residues accumulated in sedimentary basins and sustained in chemical and physical changes, as a reaction to the effects of bacterial decay, temperature, pressure and precipitated in geological time. South Sumatra Basin is known as one of the largest coal producing basins in Indonesia with Muara Enim Formation as the main coal-bearing formation. Muara Enim Formation was deposited in the regression phase making it possible for massive peatification and coalification process at the time of the formation deposition.

Cleats are opening-mode fractures formed naturally in a coal seam, cleats usually consisting of two types that are oriented perpendicular (butt cleat) and parallel (face cleat) to the coal beds (Laubach, et al., 1997). These fractures can be formed on almost coal seams so that the control of structural stability, minability and fluid flow can be identified through the presence of cleats (Mammat, 1834., Milne, 1839., quoted from Kendall and Briggs, 1933, in Laubach et al. 1997). Visually cleat is an open fracture in with no parallel offsets on the cleat wall, the cleats formed in coal are closely the same as fractures in other rocks (Dron, 1925., Kendall and
Briggs, 1993., Williamson, 1967., McCulloch Et al., 1974, 1976., Ting, 1977., Campbell, 1979., Kulander and Dean, 1990., Laubach et al., 1992, in Laubach et al., 1997). The diagenesis process is the aspect which is distinguished cleats in coal with the occurrence of fractures in igneous rocks. Cleats are formed in coal during the coal depositional process occurred whereas fractures in igneous rocks just occurred after the igneous rocks formed and undergo the deformation process.

Geographically, the research was conducted in Ulak Lebar and surrounding areas, Lahat Regency, South Sumatra. This study aims to determine the characteristics of coal seen from its megascopic and microscopic properties and to know the development and characteristics of cleats in coal seams due to the influence of tectonic regimes working on Muara Enim Formation.

\section{Regional Geology}

Regional geology conditions are basic aspects worked regionally on South Sumatra Basin, it includes in its tectonic settings and stratigraphic sequence developed from the beginning of the basin establishment to the present time. By learning the regional geology conditions intend to projects local geology conditions of the research area conveniently with the regional geology conditions of South Sumatra Basin. 


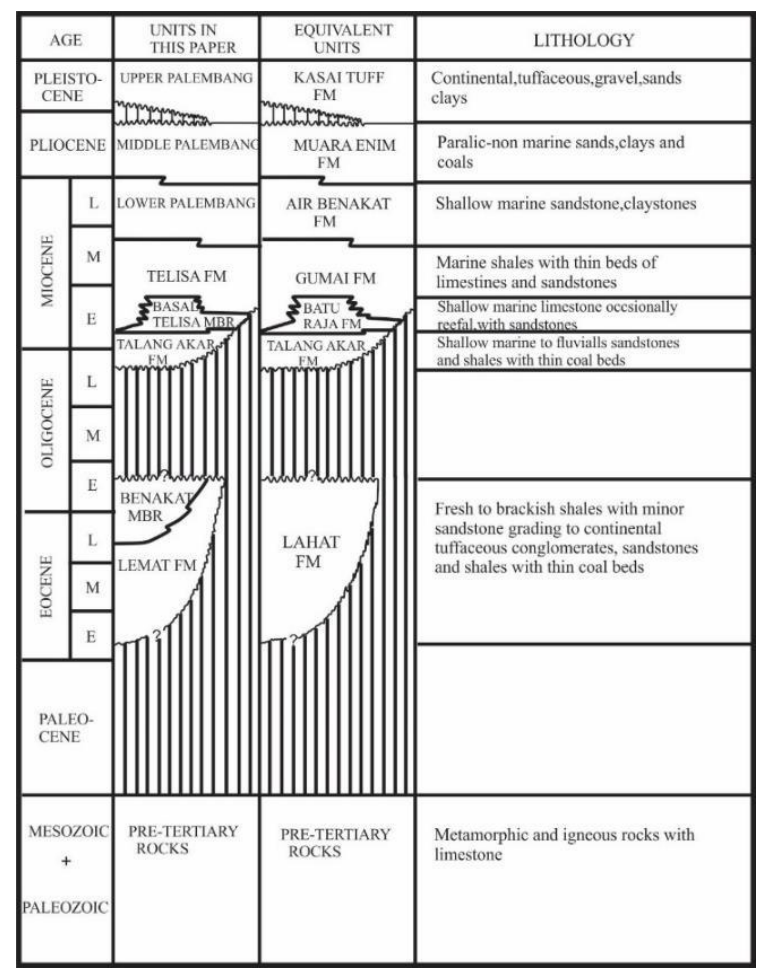

Fig. 1. Regional Stratigraphy of South Sumatra Basin (DeCoster and Addiwidjaja, 1973).

\subsection{Regional Tectonic Settings}

South Sumatra Basin is a back-arc basin formed by the subduction of Indo-Australian Plate, oriented northward to northeast towards the Eurasian Plate.The plates subduction zone covered the western part of Sumatra and the southern part of Java. The subduction affected the rock, morphological, tectonic and structural conditions in South Sumatra (Pulunggono, et al. 1992). The tectonic plates collisions on Sumatra produced forearc, magmatic and back-arc lines. According to Pulunggono, et al. (1992) tectonic events held an important role in the development of Sumatra Island and the South Sumatra Basin and were divided into four phases as follows.

- In this first tectonic phase the working stress is compression and took place in the Early Jurassic - Late Cretaceous, it produced a WNW-ESE oriented dextral strike-slip fault, such as the Lematang Fault, Kepayang, Saka, South Coast of Lampung, Musi Lineament and the N-S trend.

- The extensional stress worked in the subsequent tectonic phases occurred in the Late CretaceousEarly Tertiary, resulted in the occurrence of normal and growth faults oriented in N-S and WNW-ESE trends. The sedimentation process began at the Early Tertiary filled in the base along with the activate volcanic activity, Lahat Formation deposited in this phase.

- The following tectonic activity developed at Miocene and resulted in the uplifts of the basin edges, at the same time with the deposition of clastic materials including the deposition of Talang Akar Formation, Baturaja Formation,
Gumai Formation, Air Benakat Formation and Muara Enim Formation.

- The last tectonic event took place in Plio Pleistocene, with the compressional stress as the working one. In this phase, Kasai Formation deposited simultaneously with the occurrence of volcanism activity on the back-arc basin so that the volcanic material also deposited on the formation. Furthermore, there were north-west trending of uplifts and folds across the basin put an end to the Tertiary deposition in South Sumatra Basin.

\subsection{Regional Stratigraphy}

According to DeCoster and Addiwidjaja (1973), South Sumatra Basin is a back-arc basin which the first formation to be deposited occurred Early Eocene - Oligocene. Sequentially from the oldest to the youngest sediment deposition in South Sumatra Basin are as follows (Fig. 1).

- The basement rocks of South Sumatra Basin is consisted of metamorphic and carbonate rocks at the Paleozoic - Mesozoic aged and Mesozoic aged igneous rocks.

- Lemat Formation is the first formation to be deposited in South Sumatra Basin, it was deposited on Late Eocene - Early Oligocene. Its deposition is indicated in the deep marine environment as seen from the deposition of alluvial fan material and piedmont deposits (highland material). In addition, the sediment material deposited was poorly sorted with coarse grain-sized. The lithology composed of sand to conglomerate, coal, and also the presence of volcanic material

- During the Late Oligocene - Early Miocene the Talang Akar Formation precipitated unconformably above the Lemat Formation. This formation is deposited in the fluvial, deltaic and marginal-shallow marine environments in the global transgression phase at the time of the compressional tectonic phase. The formation is composed of shale and fine to medium grained sands.

- Baturaja Formation (Basalt Telisa Member) deposited conformably over Talang Akar Formation in Early Miocene, at the same time with the deposition of this formation, the coral growth proceeded very well. The lithology of this formation includes limestone which is very dominant, carbonated-clay and sandstone.

- Furthermore, in the Early Miocene - Middle Miocene occurred the deposition of Telisa Formation (Gumai Formation). The formation deposited over the Baturaja Formation and was composed of shale with a thin layer of limestone and sandstone. There were also the presence of glauconitic foraminifera limestone as an attribute indicating the formation was deposited in neritic environment.

- Air Benakat Formation was deposited in deep shallow marine environment, as it is indicated the end of transgression phase. The formation 
was deposited during Middle Miocene - Late Miocene and is composed of a dark gray to bluish to a dark gray to brownish colored clay, medium to fine grained glauconite sandstone glauconite with light green - brownish gray colored containing quartz and feldspar, and the intercalation of sandstone, claystone, siltstone and shale with a thin inserts of quartz sands.

- Over the Air Benakat Formation, the Muara Enim Formation was deposited conformably during Late Miocene - Pliocene. The deposited material in the formation derived from the shallowmarine, delta plain and non-marine environment, its precipitation occurred along with the decreases of sea level phase (regression phase). Muara Enim Formation consists of sandstones, claystone, and coal.

- At the Late Pliocene - Pleistocene Kasai Formation was deposited above Muara Enim Formation. Kasai Formation is the youngest formation occurred on the basin, composed of tuffaceous sandstone, claystone, conglomerate and tuff with lignite, formed during the deformation of Barisan Mountains.

\section{Research Methods}

The method used in the research is done through three stages, such as literature study, field observation and laboratory test. The earliest stage is a literature study, conducted before going directly into the field. The next stage is field observation, it is the data-gathering activity in field and the last stage is laboratory test which is done after going back from the field.

The first step to recognize the regional geology and the local geology conditions in the research area. It is intended to give a representation of what to do and what data should be collected in the fields. The literature study conducted by reading the literature such as journal, paper, proceedings and regional geological map of destination area which has been published by previous researchers.

Secondly, Field observation activities includes the data-gathering required for analysis and interpretation purposes. In this study, field observations included observations of the physical megascopic properties of coal outcrops as well as the analysis of cleat attributes such as orientation, aperture, spacing and length measurements at several observation stations.

Then, laboratory tests are conducted with coal maceral analysis, aiming to know the maceral and minerals composition in a coal sample, it is closely related to the plant species and the depositional environment conditions at the time of coalification process. The result was grouped into vitrinite groups, liptinite groups, and inertinite groups as well as the percentage of mineral matter.

\section{Results and Discussion}

Geographically, the research location is included in the administrative area of Lahat Regency, South Sumatra precisely in Ulak Lebar and surrounding area, West Merapi Districts. The research area is a part of Muara Enim Formation deposited in Late Miocene - Early Pliocene. The fractures-forming in the coal seams can be affected by the sedimentation process or local geological structures control developed in the area. Observations on coal outcrops in the study area were conducted in three observation stations, namely LP 2A, LP 2B and LP 67 (Fig. 2).

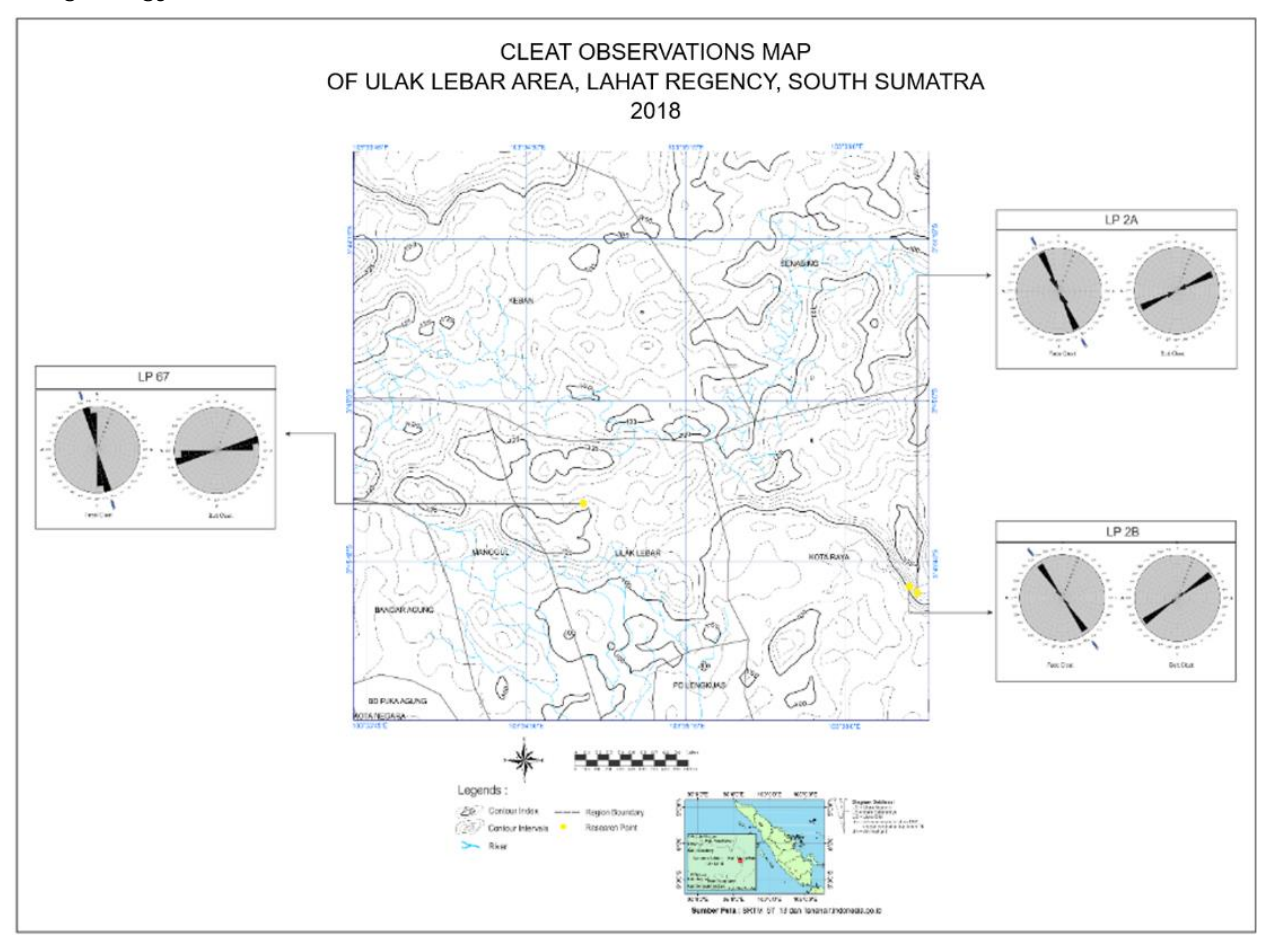

Fig. 2. Cleat observations Map of Ulak Lebar Area, Lahat Regency. 


\subsection{Coal Characteristics}

The coal outcrops found is in a former public mining field which is no longer producing. As for the outcrops observed originated from the same coal seam that the coal megascopic physical appearance in these three observation stations are relatively the same. Coal in this area has a brownish-black color with brown strike, dull luster, brittle, conchoidal fractures and has a relatively light weight. The coal seam has a relatively gentle sloping with the thickness ranging from $2-3$ meters. Furthermore, the overburden layers consists of gray to brownish claystone and white to yellowish white sandstone (Fig. 3).

Maceral is the primary material of coal constituents that is associated with each other in varying proportions. The association of this maceral in megascopic-form called lithotypes. Lithotypes can be observed in the form of thin bands with a thickness of from a few millimeters to several centimeters. The coal lithotype in the study area is durain as seen from the coal physical appearance and description. Meanwhile, the result of the maceral analysis performed on a coal sample (Table 1) shows that the coal in the research area is dominantly composed of vitrinite maceral with a percentage of $74.8 \%$ and the maximum vitrinite reflectance value amount $0.40 \%$ According to the Ward (1984) classification, such a percentage Rv max value indicates the coal in the research area is included in sub-bituminous rank (Table 2 ).

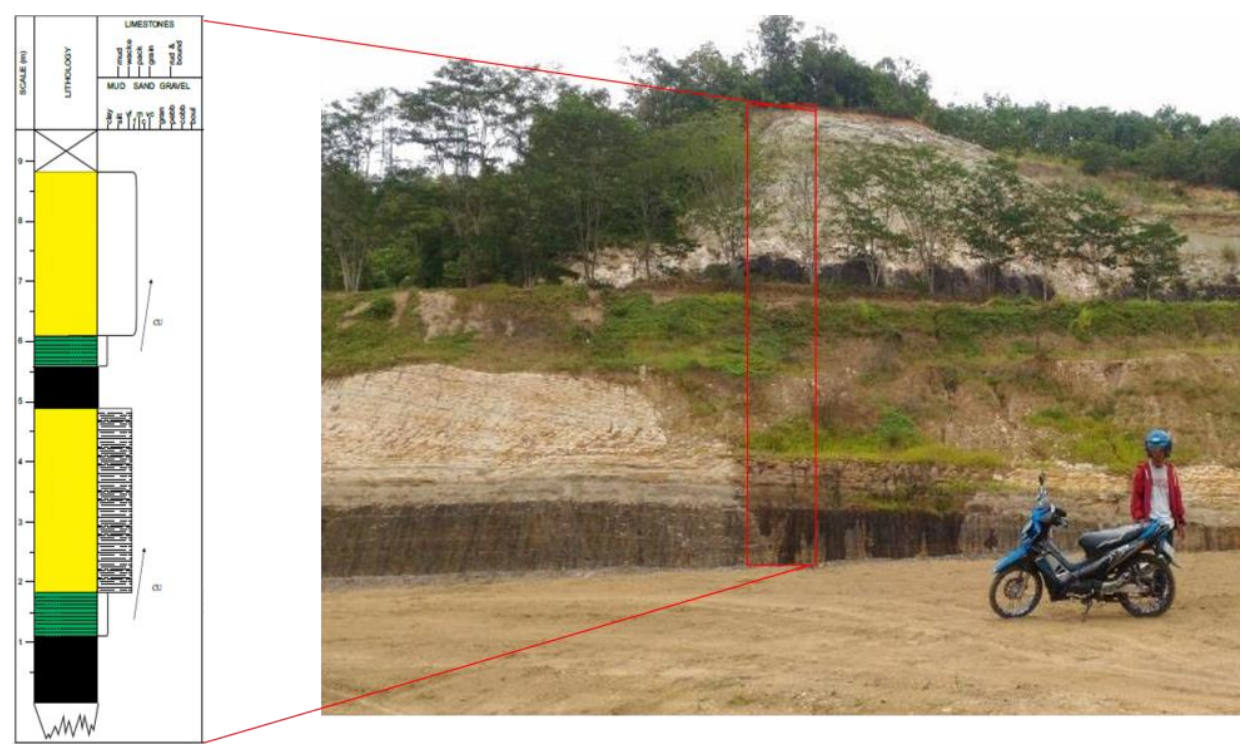

Fig. 3. Stratigraphic profile of coal outcrop at LP 2 , shows coal thickness at seam $2 A \pm 1.5$ meter and seam $2 B$ o,7 meter. The picture is taken facing east.

Table 1. Result of Muara Enim Formation Coal Maceral Analysis in the research area.

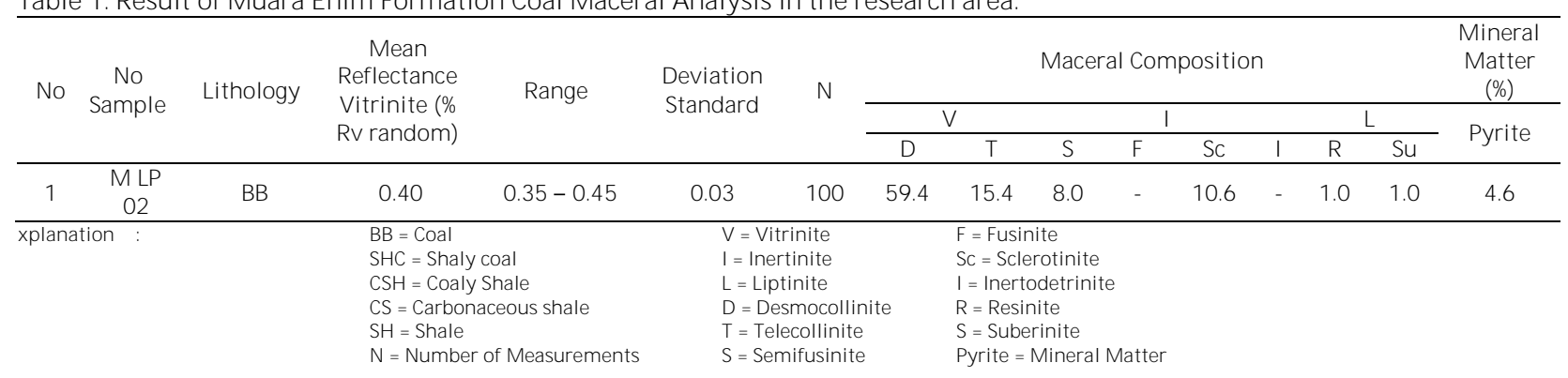

Table 2. Coal rank classification based on vitrinite maximum reflectant value (after Ward, 1984).

\begin{tabular}{cc} 
RANK & $\begin{array}{c}\text { MAXIMUM REFLECTANCE } \\
\text { (\%Rv Max) }\end{array}$ \\
\hline Sub-Bituminous & $<0.47$ \\
High Volatile Bituminous C & $0.47-0.51$ \\
High Volatile Bituminous B & $0.51-0.71$ \\
High Volatile Bituminous A & $0.71-1.10$ \\
Medium Volatile Bituminous & $1.10-1,50$ \\
Low Volatile Bituminous & $1.50-2.05$ \\
Semi-Antrachite & $2.05-3$ (approx) \\
Anthracite & $>3.00$ \\
\hline
\end{tabular}




\subsection{Cleat Attributes Analysis}

The cleat attributes analysis was conducted on three observation stations, namely LP 2A, LP 2B and LP 67. From these three locations, the analysis results were obtained (Table 3 ) as follows.

- In LP 2A observation station, the face cleat orientation was $\mathrm{N} 301^{\circ} \mathrm{E}$, and butt cleat orientation was $\mathrm{N} 040^{\circ} \mathrm{E}$ with maximum stress level at $\mathrm{N} 310^{\circ} \mathrm{E}$ and minimum stress level at $\mathrm{N} 220^{\circ} \mathrm{E}$ (Fig. 4). The cleat aperture is relatively valued $0.05-0.2 \mathrm{~cm}$ and the spacing value ranged from $6-9 \mathrm{~cm}$.
- In LP 2B observation station, the face cleat orientation was $\mathrm{N} 284^{\circ} \mathrm{E}$, and butt cleat orientation was $\mathrm{N} 030^{\circ} \mathrm{E}$ with maximum stress level at $\mathrm{N} 290^{\circ} \mathrm{E}$ and minimum stress level at $\mathrm{N} 200^{\circ} \mathrm{E}$ (Fig. 5). The cleat aperture is relatively valued $0.05-0.25 \mathrm{~cm}$ and the spacing value ranged from $5.5-8.6 \mathrm{~cm}$.

- In LP 67 observation station, the face cleat orientation was $\mathrm{N} 290^{\circ} \mathrm{E}$, and butt cleat orientation was $\mathrm{N} 010^{\circ} \mathrm{E}$ with maximum stress level at $\mathrm{N} 295^{\circ} \mathrm{E}$ and minimum stress level at $\mathrm{N} 205^{\circ} \mathrm{E}$ (Fig. 6). The cleat aperture is relatively valued $0.1-0.3 \mathrm{~cm}$ and the spacing value ranged from $1.5-3.3 \mathrm{~cm}$.
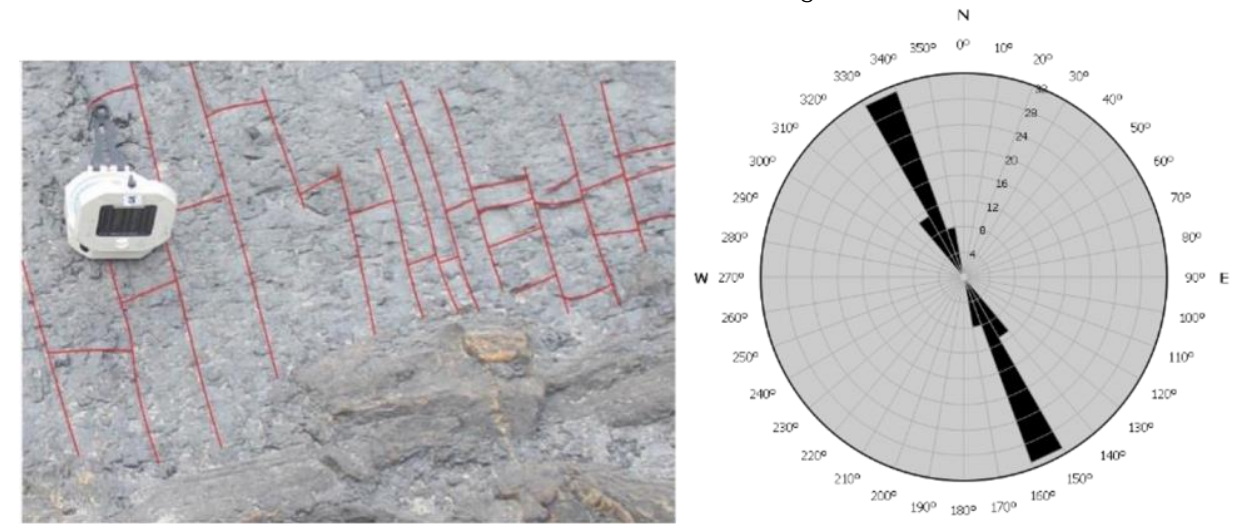

Fig. 4. Face cleat orientation of LP 2A
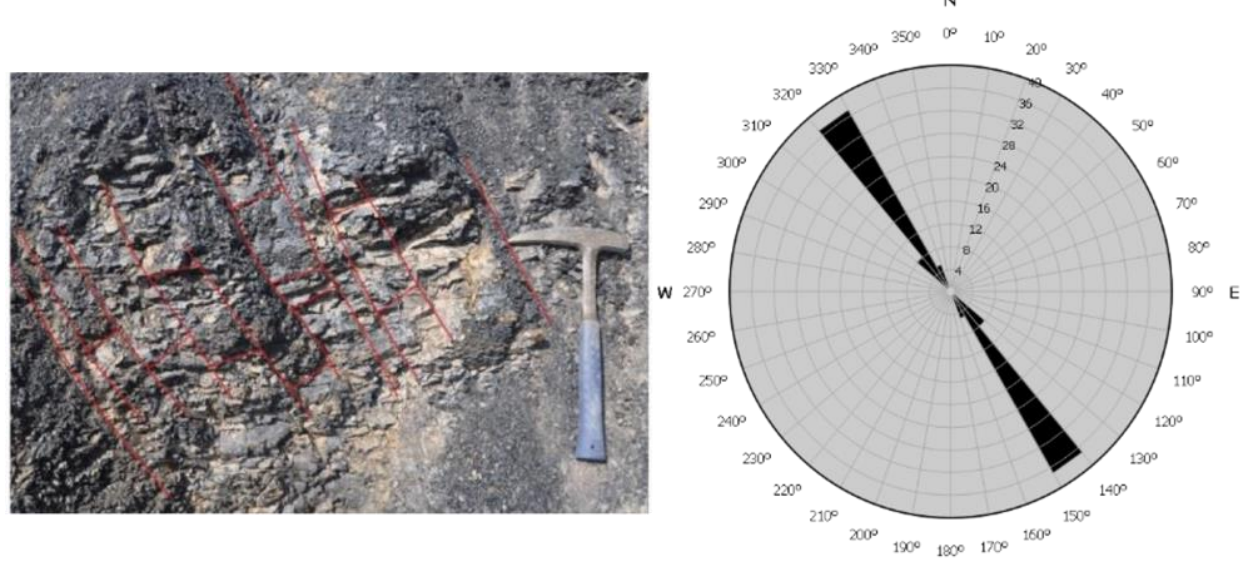

s

Fig. 5. Face cleat orientation of LP 2B
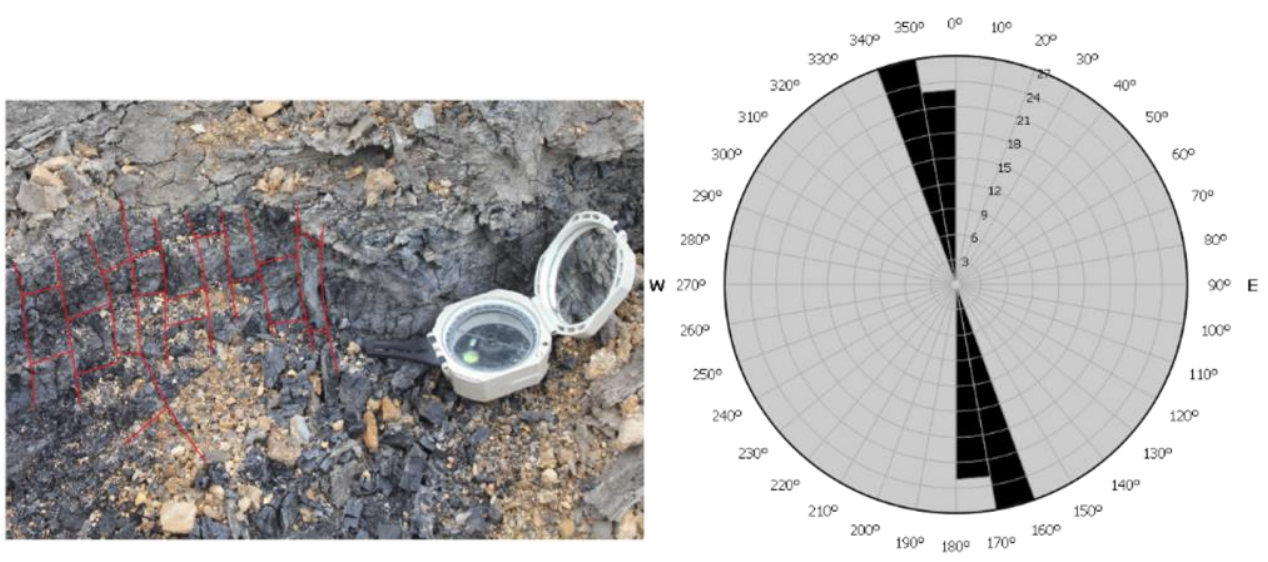

Fig. 6. Face cleat orientation of LP 67 
In general, the cleat orientation formed NW - SE trending, with the value of the aperture, formed relatively the same ranges between $0.05-0.3 \mathrm{~cm}$ with open-mode fractures and partially filled with clay and pyrite minerals. There is a considerable contrast to the cleats spacing value on LP 67 towards the LP 2A and LP 2B ones, the cleats spacing value of LP 67 tend to be more dense and intense. The determination of cleats genesis is done by dividing the genesis based on the rotation angle of the cleat to the bedding plane wherein if the resulting angle between $70-90^{\circ}$ is classified as endogenic cleat and if the resulting corner $<70^{\circ}$ is classified as an exogenic cleat (Apriyani, N „, et al, 2013).

The cleat orientation in the research area is relatively northwest-southeast oriented and in contrast to the orientation of regional structures at the research area, which is in northeast-southwest oriented. Based on the cleat rotation data plot, the resulting angle is at intervals from 67 to $84^{\circ}$ (Fig. 7) so that the majority of cleats in the study area are genetically included in the endogenic cleats in which their formation is influenced by the internal stress in the coalification process resulting from the coal matrix shrinkage. The cleats obtained are almost perpendicular to the bedding plane of coal.

The relationship between coal maturity levels is inversely proportional to the presence of cleats in a coal seam. More cleats shows that the maturity level of the coal is not high yet, the higher the maturity level of the coal the less presence of cleat obtains in the coal seams. In the research area, cleats developed quite well, in LP 2A and 2B there are even pyrite minerals that fill the fracture. The presence of these minerals also affects the coal quality because it causes an increase in mineral matter content, thereby reducing the calorific value of coal.

Table 3. Comparisons of cleat attributes in each observation stations.

\begin{tabular}{|c|c|c|c|c|}
\hline \multicolumn{5}{|c|}{ Face Cleat } \\
\hline \multirow{2}{*}{ No } & \multirow{2}{*}{ Cleat Components } & \multicolumn{3}{|c|}{ Observation Stations } \\
\hline & & LP 2A & LP 2B & LP 67 \\
\hline \multirow[t]{4}{*}{1.} & a. Strike/dip & $\mathrm{N} 298^{\circ} \mathrm{E} / 11^{\circ}$ & $\mathrm{N} 296^{\circ} \mathrm{E} / 11^{\circ}$ & $\mathrm{N} 288^{\circ} \mathrm{E} / 15^{\circ}$ \\
\hline & b. Orientation & $\mathrm{N} 301^{\circ} \mathrm{E} / \mathrm{N} 121^{\circ} \mathrm{E}$ & $\mathrm{N} 284^{\circ} \mathrm{E} / \mathrm{N} 104^{\circ} \mathrm{E}$ & $\mathrm{N} 290^{\circ} \mathrm{E} / \mathrm{N} 110^{\circ} \mathrm{E}$ \\
\hline & c. Max. stress level & $\mathrm{N} 310^{\circ} \mathrm{E} / \mathrm{N} 130^{\circ} \mathrm{E}$ & $\mathrm{N} 290^{\circ} \mathrm{E} / \mathrm{N} 110^{\circ} \mathrm{E}$ & $\mathrm{N} 295^{\circ} \mathrm{E} / \mathrm{N} 115^{\circ} \mathrm{E}$ \\
\hline & d. Min. stress level & $\mathrm{N} 040^{\circ} \mathrm{E} / \mathrm{N} 220^{\circ} \mathrm{E}$ & $\mathrm{N} 020^{\circ} \mathrm{E} / \mathrm{N} 200^{\circ} \mathrm{E}$ & $\mathrm{N} 025^{\circ} \mathrm{E} / \mathrm{N} 205^{\circ} \mathrm{E}$ \\
\hline 2. & Aperture $(\mathrm{cm})$ & $0.05-0.2$ & $0.05-0.25$ & $0.1-0.3$ \\
\hline 3. & Spacing $(\mathrm{cm})$ & $6-9$ & $5.5-8.6$ & $1.5-3.3$ \\
\hline \multirow[t]{2}{*}{4.} & Mineral fill & Pyrite & Clay minerals & - \\
\hline & \multicolumn{4}{|c|}{ Butt Cleat } \\
\hline 5. & a. Strike/dip & $\mathrm{N} 049^{\circ} \mathrm{E} / 13^{\circ}$ & $\mathrm{N} 041^{\circ} \mathrm{E} / 13^{\circ}$ & $\mathrm{N} 029^{\circ} \mathrm{E} / 14^{\circ}$ \\
\hline & b. Orientation & $\mathrm{N} 040^{\circ} \mathrm{E} / \mathrm{N} 220^{\circ} \mathrm{E}$ & $\mathrm{N} 030^{\circ} \mathrm{E} / \mathrm{N} 210^{\circ} \mathrm{E}$ & $\mathrm{N} 010^{\circ} \mathrm{E} / \mathrm{N} 190^{\circ} \mathrm{E}$ \\
\hline 6. & Aperture $(\mathrm{cm})$ & $0.05-0.09$ & $0.05-0.1$ & $0.1-0.2$ \\
\hline 7. & Spacing (cm) & $4-7$ & $4-8$ & $1-2$ \\
\hline 8. & Mineral fill & - & - & - \\
\hline
\end{tabular}

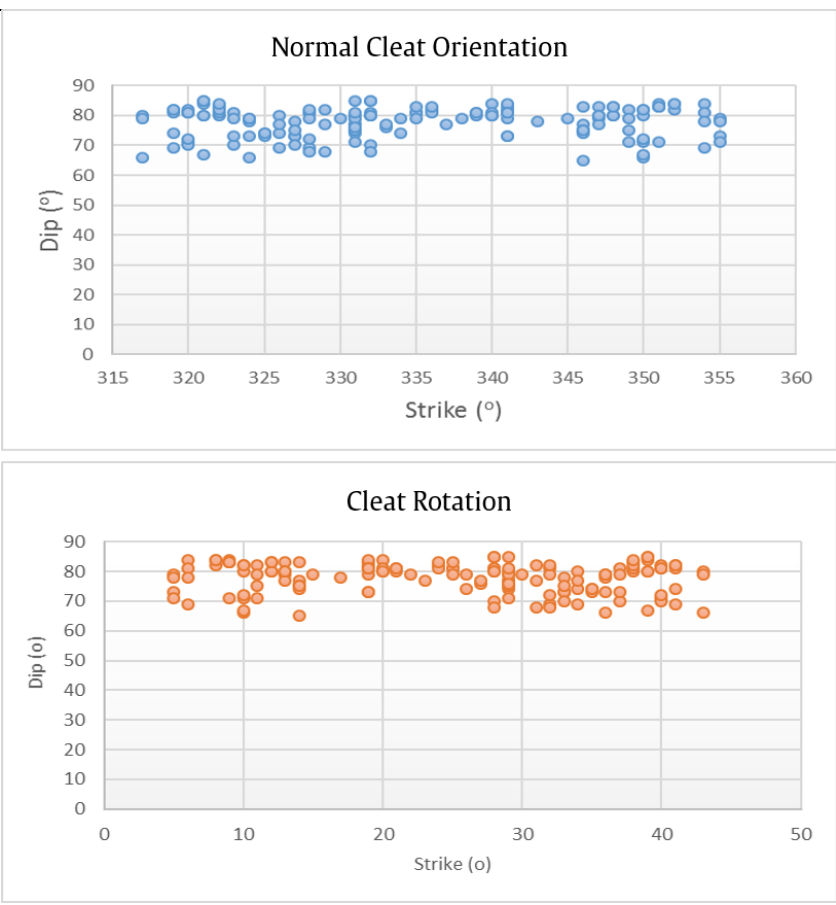

Fig. 7. Normal cleats orientation and cleat rotation. 


\section{Conclusions}

Based on this research, it can be concluded as follows :

1. The coal outcrops found in the research area were part of Muara Enim Formation deposited during Late Miocene - Pliocene.

2. Physically, the coal obtained in Ulak Lebar and surrounding area has blackish brown to black color, dull luster, brittle, conchoidal fractures, and relatively light-weight with coal seam thickness ranging between 2 to 3 meters. Based on its megascopic appearance the coal lithotype in the research area is in durain category Based on the maceral analysis conducted on a coal sample, the coal in the research area is dominantly composed of vitrinite maceral (74,8\% in composition) and the maximum vitrinite reflectance value amount 0.40 , indicating the coal in the research area included in sub-bituminous rank.

3. The cleats orientation in the research relatively NW - SE oriented, with the value of the aperture formed relatively the same ranges between 0.05 - $0.3 \mathrm{~cm}$ with open-mode fractures and partially filled with clay and pyrite minerals.

4. Most of the cleats in the study area are genetically included in the endogenic cleats in which is the formation is influenced by the internal stress in the coalification process resulting from the coal matrix shrinkage.

\section{Acknowledgments}

Acknowledgments are addressed to the whole lecturers of Geology Department Sriwijaya University, especially for Mrs. Idarwati, S.T., M.T who has guided and assisted in interpreting the geological conditions in the research area, as well as our colleagues in the class who have provided us critics, suggestions and discussions in completing this study.

\section{REFERENCES}

Adiwidjaja, P. and Decoster, G.L. 1973. Pre-Tertiary Paleotopography And Related Sedimentation In South Sumatra . Bulletin of Proceedings Indonesian Petroleoum Associations, 2

Amijaya, H., Littke, R., 2005. Properties of Thermally Metamorphosed Coal from Tanjung Enim Area, South Sumatra Basin, Indonesia with Special Reference to the Coalification Path of Macerals. International Journal of Coal Geology 66 (2006) 271 - 295.

Anggayana, K., 2002. Genesa Batubara. Departemen Teknik Pertambangan., FIKTM, Institut Teknologi Bandung.
Apriyani, N., Suharmono, Momen, M., Djaelani, S., Sodli, A., Satria, A., Murtani, A.,S., 2013. Integrated cleat analysis and coal quality on cbm exploration in Sangatta II Field, Kutai Basin, East Kalimantan. Proceedings Indonesian Petroleum Association, 37.

De. Coster G. L.,1974, The Geologi of Central Sumaatera nad South Sumatera Basins, Proceeding Indonesian petroleun Assoc, 4th Annual Convention

Krestanu, A., Iqbal, M., Fernando, R. E., Herawati., Puadi, M., 2016, Karakteristik Cleat Batubara Terhadap Intensitas Struktur Pada Desa Merapi Timur, Kabupaten Lahat di Formasi Muara Enim, Cekungan Sumatera Selatan. Proceeding, Seminar Nasional Kebumian Ke-9. p. 211215

Lamberson, M.N., Bustin, R.M., Kalkreuth, W. (1991) Lithotype (maceral) composition and variation as correlated with paleowetland environments, Gates Formations, Northeastern British Columbia. Canada; International Journal of Coal Geology 18. p. 87-124

Laubach, S. E., Marret, R. A., Olson, J. E., Scott, A. R., 1998. Characteristics and origins of coal cleat: A review. International Journal of Coal Geology 35 (1998) 175207.

Nasution, F. P., Nalendra, S. 2017. Characterization of Coal Quality Based On Ash Content From M2 Coal-Seam Group, Muara Enim Formation, South Sumatra Basin. Journal of Geoscience Engineering, Environment, and Technology, Vol 2 No. 3. p. 203-209

Nichols, G. (2009). Sedimentology and Stratigraphy Second Edition, Wiley-Blackwell: London

Prayitno, B., Ningrum, N. S. 2017. Development of Funginite on Muaraenim and Lower Members of Telisa Formations at Central Sumatra Basin - Indonesia. Journal of Geoscience Engineering, Environment, and Technology, Vol 2 No. 2. p. 149-154

Pulunggono, A., S, Agus Haryo., Kosuma, Christine. G., 1992. Pre-tertiary and tertiary fault system as a framework of the South Sumatra Basin: A study of SAR-MAPS. Proceedings Indonesian Petroleum Associations Twenty First Annual Convention, IPA 9211. 37.

Putra, D. B. E., Choanji, T. 2016. Preliminary Analysis of Slope Stability in Kuok and Surrounding Areas. Journal of Geoscience Engineering, Environment, and Technology, Vol 1 No 1. p. 41-44.

Sari, S. L., Rahmawati, M. A., Triyoga, A., Idarwati. 2017. Impact of Sulphur Content on Coal Quality at Delta Plain Depositional Environment: Case study in Geramat District, Lahat Regency, South Sumatra. Journal of Geoscience Engineering, Environment, and Technology, Vol 2 No. 3. p. 183-190.

Stopes, M.C. (1935).On the Petrology of Banded Bituminous Coals: Fuel , Vol. 14, 4-13

Sudarmono,. T, Suherman., Eza, Benny., 1997. Paleogene basin development in sundaland an itd role to time petroleum system in Western Indonesia. Petroleum system of SE Asia and Australia conference, May 1997. IPA 97-OR-38.

Ward, C.R. (1986). Review of Mineral Matter in Coal, Australian Coal Geology,Geol.Soc. of Australia, Vol. 6 pp. 87-107. 